\title{
THE DEFIANCE OF THE TRANSCENDENTAL BY PHANTASY AND IMAGINATION IN HUSSERL AND KANT
}

\author{
AZUL KATZ \\ PhD Student in Philosophy. \\ University of Buenos Aires. \\ 1014 CA Buenos Aires, Argentina. \\ Paris IV-Sorbonne University. \\ 75005 Paris, France.
}

E-mail: azulkatz@gmail.com

The present paper explores the place that imagination and phantasy hold in the transcendental philosophies of Kant and Husserl when they are not subordinated to functions that are external to them. The Kantian imagination (Einbildungskraft) has a key function within reason, both theoretical and practical, but it seems to exhibit its true potential in the aesthetic subjective domain, as productive imagination - in addition, this aesthetic domain is defined as the most properly human. In Husserl's work, phantasy (Phantasie) has a relevant methodological function in the intuition of essences and plays other constituting roles, for example in empathy - and therefore in intersubjectivity. Nevertheless, the Husserlian phantasy shows its full potential not when it is bound to a presentation through perception - as it does in its constituting functions, but when it is pure and moves freely in an enlarged eidetic sphere. Husserlian phantasy would not only allow the transit from facts to essences, but it would also allow the reverse path, limiting essences towards facticity. In this framework, a final consideration points to the challenges raised by the exploration of this intermediate sphere of experiences involving productive imagination and pure phantasy, regarding the hierarchy and margins of the transcendental constitution.

Key words: Kant, Husserl, phantasy, imagination, transcendental philosophy, subjectivity, intersubjectivity.

(C) AZUL KATZ, 2018

HORIZON 7 (1) 2018 


\title{
ВЫЗОВ ФАНТАЗИИ И ВООБРАЖЕНИЯ ТРАНСЦЕНДЕНТАЛЬНОМУ У ГУССЕРЛЯ И КАНТА
}

\author{
АСУЛ КАЦ \\ Аспирант. \\ Университет Буэнос-Айреса. \\ 1014 СА Буэнос-Айрес, Аргентина. \\ Университет Париж IV - Сорбонна. \\ 75005 Париж, Франция. \\ E-mail: azulkatz@gmail.com
}

В данной статье исследуется место воображения и фантазии в трансцендентальной философии Канта и Гуссерля, поскольку они не подчинены внешним для них функциям. Воображение в кантовском смысле (Einbildungskraft) исполняет ключевые функции в сфере разума - как теоретического, так и практического. Но, пожалуй, у Канта оно более всего проявляет свой потенциал в субъективной области эстетики в качестве продуктивного воображения. Эта эстетическая сфера характеризуется более других в качестве собственно человеческой. В трудах Гуссерля фантазия (Phantasie) исполняет релевантную методологическую функцию в созерцании сущности и играет другие когнитивные роли. Например, это имеет место в случае эмпатии, а стало быть - интерсубъективности. Впрочем, фантазия в гуссерлевском смысле полностью проявляет свой потенциал не тогда, когда она связана с представлением посредством восприятия, но тогда, когда она является чистой и свободно движется в расширенной эйдетической сфере. Фантазия в гуссерлевской трактовке допускает не только переход от фактов к сущностям, но она допускает также и обратный путь, ограничивающий сущности в направлении фактичности. В этом контексте заключительное рассмотрение делает акцент на том, что проблемы, создаваемые этой опосредующей сферой опыта, включают продуктивное воображение или чистую фантазию в иерархию устройства трансцендентального.

Ключевые слова: Кант, Гуссерль, фантазия, воображение, трансцендентальная философия, субъективность, интерсубъективность.

\section{A TRANSCENDENTAL FERNASPEKT}

Husserl's ambivalent relationship to Kant is a fact well established by excellent and well-known works that have identified, both historically and systematically, the points of agreement and disagreement between both thinkers ${ }^{1}$, and by the amount of works that have either sustained ${ }^{2}$ or denied $^{3}$ the affiliation of Husserl's philosophy to Kant's. Those who argue that Husserl is at the antipodes of Kant rely, for example, on

1 Among the most significant: cf. Kern (1964) and Pradelle (2012).

2 Ricoeur (1986) has tried to establish (with historical omissions) a Kantian-Hegelian affiliation of Husserl's Phenomenology.

3 S. Bachelard, La logique de Husserl, as cited in Kelkel (1966). 
the Husserlian rejection of Kant and Neo-Kantianism during the years in which he was Brentano's disciple, in the consequent privileging of English empiricism, and in the recurrent references to the Cartesian ego cogito as the original discovery of transcendental subjectivity ${ }^{4}$. Those who establish a filiation often rely on the relationship between the Husserlian transcendental turn and the Copernican Revolution that gave rise to Critical-Transcendental Philosophy. The present paper does not aim to review Husserl's reconsideration of Kant's thought, its true influence on the phenomenological-transcendental turn, or its motivations and limitations. On the contrary, the present paper takes transcendentalism as its starting point, without pretending to dissolve the ambivalent relation between Husserl, on the one hand, and Kant and neo-Kantianism, on the other. As Husserl indicates in his famous conference of May 1, 1924, delivered in Freiburg for the bicentenary of Kant's birth, Kant und die Idee der Transzendentalphilosophie (Husserl, 1956), taken "a certain distance, as if we were surveying from a distant point a mighty mountain range that we had often wandered through with an indefatigable interest in getting to know it, and now only the general formation, the total type, emerges for us" (Husserl, 1956, 239), "[t]he completely total global form (Fernaspekt) of the Kantian philosophy in its distant aspect is the idea of transcendental philosophy" (Husserl, 1956, 239). I believe this to be valid for both authors, that is, at a certain distance Kant and Husserl share certain spirit of transcendentalism.

Husserl considers himself an heir of the Copernican revolution. But to assume the Kantian inheritance does not mean, for Husserl, "to welcome his system as it is, or to improve its details, this is not what is necessary above all else, but rather to understand the ultimate sense of his revolution - and to understand him better than he himself, the trailblazer, but not the perfecter, was capable of doing" (Husserl, 1956, 286). In this sense, Husserl considers that the Copernican revolution, which is "the eternal glory" of Kant, must lead "to an essentially new and, moreover, rigorously scientific interpretation of the meaning of the world" (Husserl, 1956, 240).

Transcendental, therefore, is said in many ways. For Kant, the task of critical-transcendental philosophy is the determination of the limits and possibilities of experience from an investigation into pure reason ${ }^{5}$. Although transcendental in Kant's thought is one of the most difficult terms, in a general sense it is a predicate of necessary and uni-

4 Husserl argues that Kant's philosophy is based on the merit of the Cartesian philosophy: "The ego cogito, understood in its profound sense, can surely be regarded as the first form of the discovery of transcendental subjectivity" (Husserl, 1956, 241). All translations here and in what follows are mine, unless indicated otherwise, and they are contrasted with English translations when available.

5 "Our ability to cognize from a priori principles may be called pure reason, and the general inquiry into the possibility and bounds of such cognition may be called critique of pure reason" (Kant, 1908, 167). 
versal validity. Thus, for example, the conditions for all objectivity are transcendental conditions (the categorical synthesis and the unity of consciousness) because they are necessarily applied to every object. Transcendental cognition is a second-order cognition: "I call all cognition transcendental that is occupied not so much with objects but rather with our mode of cognition of objects insofar as this is to be possible a priori" (Kant, 1903, 11), that is to say that it is cognition of the necessary conditions of a priori cognition. According to Kant, transcendental cognition deals with "the critique of cognitions" (Kant, 1911, 81). Something is said to be transcendental when the possibility of a priori cognition is based on that something (Kant, 1911, 132, 151). Transcendental cognition can first be distinguished from the logical-formal structures of thought; second, it is also opposed to transcendent cognition (Kant, 1911, 300, 303, 406, 524); third, since it deals only with pure a priori conditions of experience (Kant, 1911, 829), it is independent from experience (Kant, 1911, 829 note) and in this sense it is opposed to empirical cognition; and, finally, not all a priori cognition is transcendental, so that it also opposes other a priori cognitions, such as, for example, geometry ${ }^{6}$. Transcendental philosophy studies the faculties of $a$ priori cognition and its functions, but not all the functions of a faculty are transcendental, since they are not all conditions of the possibility of our experience. For example, imagination is called transcendental not in all its operations, but only in its synthetic operations, that is, those that allow the application of pure concepts to the manifold given in sensibility (Kant, 1903, 118, 123) ${ }^{7}$.

Now, in correspondence with two kinds of concepts, that of nature and that of freedom (Kant, 1908, Introd. I, II), criticism establishes a limit between the theoretical sphere - the knowable (kennbar) - and the practical sphere - the thinkable (denkbar). "Hence an immense gulf (eine unübersehbare Kluft) is fixed between the domain of the concept of nature, the sensible (Sinnlichen), and the domain of the concept of freedom, the supersensible (Übersinnlichen)", thus obstructing all "possible transit"

6 Since defining transcendental is not my aim, here I have followed Rudolf Eisleir's Kant-Lexikon (Eisleir, 1989) and Mario Caimi’s Diccionario de la filosofía crítica kantiana (Caimi, 2016).

7 "Thus the transcendental unity of apperception is related to the pure synthesis of the imagination, as an a priori condition of the possibility of all composition of the manifold in a cognition. But only the productive synthesis of the imagination can take place a priori; for the reproductive synthesis rests on conditions of experience. [...] Now we call the synthesis of the manifold in imagination transcendental if, without distinction of the intuitions, it concerns nothing but the connection of the manifold a priori, and the unity of this synthesis is called transcendental if it is represented as necessary a priori in relation to the original unity of apperception. Now since this latter is the ground of the possibility of all cognitions, the transcendental unity of the synthesis of the imagination is the pure form of all possible cognition, through which, therefore, all objects of possible experience must be represented a priori" (Kant, 1903, 118). 
between both spheres (Kant, 1908, 175). It is this limit to what can be experienced that leads Ricoeur to define Kant's philosophy as a phenomenology in tension with an impossible ontology. Ricoeur also argues that the Kantian problem of the limit (Grenze) will be replaced in Husserl by the problem of fullness (Fülle), so that, in phenomenological terms, it would be necessary to say that the phenomenal is that what can be fulfilled, while, the noumenal is essentially that what can only be intentioned emptily.

In the case of Husserl, the transcendental is opposed not to the empirical, but to the natural, since to philosophize he considers necessary a shift out of the naïve natural attitude of merely believing in the existence of the world. Therefore, Husserl interprets Kant's Copernican revolution in terms of an inversion of the natural way of thinking, whose fundamental meaning is "to bring to light the sphere, absolutely hidden until then, of the 'pure' subjectivity and the infinite horizon of the transcendental problematic" (Husserl, 1956, 243). Thus, the importance of the transcendental reduction, which allows this shift from a credulous attitude to an attitude in which, through reflection, the true nature of experience as constituted in a transcendental subjectivity appears. But the transcendental reduction is not enough for phenomenology to be constituted as a rigorous science. There must also be a shift from facts to essences, that is, there must also occur an eidetic reduction ${ }^{8}$. So transcendental phenomenology, after phenomenological reduction, is opposed both to the natural and to the factual. A parallel can thus be established between two features of the Kantian critical philosophy, the a priori or non-empirical and the universal or non-particular, and two notes of the Husserlian phenomenology, the transcendental, understood as the non-natural, and the eidetic, understood as the non-factual.

It is necessary to emphasize that both philosophies are also constructed in a spirit of hierarchy. As Deleuze argues, the Kantian system is a system of ends organized hierarchically, in which the transcendental method implies an "immanent criticism, reason as a judge of reason", which sets out to determine "1. the true nature of the interests or ends of reason; 2. the means to realize those interests" (Deleuze, $1963,8)$. With the discovery of principles in pure reason, autonomous areas of interest

8 According to a well-established research by Oskar Becker the transcendental reduction converts the mundane object into a pure phenomenon, that is, a phenomenon for consciousness, and the eidetic reduction excludes the contingent and leads to the vision of the essence. In this sense, phenomenological reduction requires not only a reduction to the transcendental sphere, but also a reduction to the eidetic one. In addition to the fact that both reductions can be carried out independently, transcendental phenomenology can be reached starting from either of the two reductions. From the real fact, one can first go to capture its essence, and then move on from it to the pure phenomenon. Or one can first go to the pure phenomenon as a singular factum, and then advance to the eidetic dimension to reach the transcendental phenomenon in its essential features (Becker, 1973). 
emerge (the theoretical-cognitive interest, the practical-moral interest and, later and relatively, the aesthetic-teleological interest), which are called superior faculties of the mind (Vermögen des Gemüts). Within each interest, the faculties of cognition (Erkenntnis Vermögen) come into concordance and align behind one faculty of cognition that takes the position of legislator in the attainment of one of the interests of reason: the understanding in cognition, reason in morality, and judgment in aesthetic and teleological experience.

This spirit of hierarchy also governs the philosophy of Husserl, mainly in a model of foundation (Fundierung), according to which acts are founded on one another allowing the emergence of increasingly complex experiences. Acts such as feelings of liking and dislike, approval or disapproval, valuation or disvaluation, pane and pleasure, and values of all kinds, are, according to Husserl, intentional acts, since the objectifying act upon which they are founded lend them the intentional directedness to an object $^{9}$. So here, the spirit of hierarchy may be even stronger than in Kant, not leading to a model of autonomy, since for Husserl the practical sphere of values, latter on the Wertslehre, is founded upon the theoretical sphere (objectifying acts), without which no experience ${ }^{10}$ would be possible.

The Husserlian model of foundation, for its part, also manifests an intellectualism, in the sense of the priority of the objectifying acts that are the basis of any experience ${ }^{11}$. All experience remits or returns, ultimately, to a foundational sensible impression ${ }^{12}$, so it can be argued that in Husserl there is a priority of theoretical reason. While it is true that in the Kantian system practical reason has priority (freedom

9 Cf. the Fifth Logical Investigation, where Husserl discusses Brentano's concept of foundation (Husserl, 1984).

10 Of course as phenomenology encounters a genetic direction in its analysis, this assertion is not entirely true.

11 "The Husserlian conception of intentionality is of an intellectualist type because it is characterized by a primacy of the theoretical relationship, of the relation of cognition. Reality, as that which is mentioned in every intentional act, that is, the other of consciousness, can only be achieved on the basis of a theoretical consciousness, that is, of an objectification [...]. This does not mean that the acts different of the theoretical ones are not intentional: desire or joy are intentional, that is, they relate to something. But if they lie to an object, they do not give birth to their own object and there is no specific sense of being that would be correlative to them. There is no desired or joy that is not previously knowledge. In short, presence is constituted in an objectifying act, and it is on the basis of this act that other acts can be related to something, to be intentional. [...] This orientation is fundamental and, despite the variations, it will never be truly contested" (Barbaras, 2015, 95).

12 "With the latest Husserl, to found does not mean to raise to the intellectuality, but on the contrary to build on the ground of the primordial, the pre-given. It is precisely the genius of Hume: to regress from signs, symbols and images to impressions" (Ricoeur, 1954-55, 61). 
is the only absolute that escapes the contingency of the particular, thus guaranteeing morality), the strength of the critical building depends on the cognitive faculties and the principles that originate in them. In this sense, and considering for example the connecting function that the third Critique tries to accomplish between theoretical reason and practical reason (Kant, 1908), a certain Kantian intellectualism can be postulated ${ }^{13}$.

The importance of the cognitive foundation in Kant also manifests itself in the form of idealism it defends, since objectivity is reduced to the categorical synthesis that is imposed on the manifold of sensibility. Not only what is relative to the transcendental subjectivity is knowable, but also the very structures of objectivity are adapted to those of the transcendental subjectivity. Husserlian idealism, one of the most controversial points of his philosophy, lies in his understanding of the world as an intentional correlate of the constituent subjectivity or intersubjectivity. Nevertheless, this idealism does not have the same sense as in Kant, since, as Pradelle argues, Husserl reverses the Copernican revolution: objectivity is irreducible to the structures of transcendental subjectivity and rather determines the way it is apprehended $\left(\right.$ Pradelle, 2012) ${ }^{14}$.

Of course, gradation is inherent to the spirit of hierarchy. At the top lies the certainty, the fixed and indubitable truth, unity. At the bottom we will find the arbitrary, the multiple, the fluctuating, the factual. This gradual hierarchical model affects all spheres of interest of reason or consciousness. Kant also establishes a correlation between degrees and cognitive faculties: to sensibility with its manifold - when not submitted to concepts, can only aspire to a private validity, while objective validity is based on concepts and can result in objective cognition if the concepts originate in the understanding, whereas if they originate in reason they can only be thought without being able to be given and become objective.

Now, can it be asserted that the transcendental foundation is also subject to this spirit of hierarchy? Could there be degrees of transcendentality? How would these

13 It may also be recalled for example, how Nietzsche accuses Kant of legitimizing aesthetics by lending the values proper to the sphere of cognition: "Intended to pay art a tribute when he singled out from the qualities of beauty those which constitute the glory of cognition: impersonality and universality" (Nietzsche, 2006, 74).

14 See also: Husserl's fundamental theses overthrow this Copernican revolution, in a precise sense that it does absolutely no imply a return to realism: "Every object in general [...] designates a regulatory structure of the transcendental subject; instead of the a priori structures of the object being regulated on the universal structures of the finite subject, on the contrary, the constitutive structures of any subjectivity in general have their foundation in the essence of the possible intentional objects" (Pradelle, 2016, 444). 
degrees be reflected in the critical inquiry of reason and in the phenomenological inquiry of consciousness? Or would it be better to think about levels of rationality, instead of levels of transcendentality - which, in fact, would go through all levels of rationality equally? Furthermore, would there be a correlation between the supposed degrees of transcendentality and the cognitive faculties? Or should we keep a mere dualism between the transcendental and the other of the transcendental, for instance, the empirical in Kant and the natural factual in Husserl?

Husserl establishes a distinction, in a Kantian spirit, between three types of truths a community aims to reach and among which the highest are founded on the inferior ones:

Out of subjective and changing acceptances we toil to shape legitimately verified truths and truths that are to be verified at any time subjectively as well as intersubjectively, and finally - under the title of science - "ultimately valid" truths, the existent in the "true", in the ultimately valid sense. (Husserl, 1956, 260)

In this sense, as noted by Husserl in this excerpt, there is, in addition to the sphere of "subjective and changing" or private validity and, in addition to the "definitive" or scientific validity, a third kind of validity; a validity of intermediate rank, neither entirely private, nor entirely objective, conceptual or categorical, which is the validity of the "intersubjectively verifiable" truths - in Husserlian terms - or subjective validity - in Kantian terms.

Now, how are we to understand this intermediate sphere? What is the place of such a sphere of validity in the architecture of reason, in the life of consciousness? Intermediate between what other spheres according to Kant and according to Husserl? Moreover, what consequences does the recognition of such a sphere have on transcendental philosophy?

\section{AESTETICS AND EIDETICS:}

\section{BETWEEN THE TRANSCENDENTAL AND THE NATURAL-EMPIRICAL}

\section{II.1. THE AESTETHIC ESSENCE OF KANTIAN IMAGINATION}

In Kant, this intermediate sphere coincides with the subjective sphere of feeling, that is, with the superior faculty of feeling pleasure and displeasure. It is distinguished, therefore, from the sphere of receptivity, on the one hand, and the sphere of concepts, on the other. As Kant explains in the "Preface" and the "Introduction" of the Critique of Judgment, the sphere of feeling can receive a transcendental foundation only if there 
is a principle, different from the principles discovered in the first two Critiques, which also originates in reason, and that determines a certain a priori legality for its operation. This principle, which differs from the principle of conformity to law (Gesetzmässigkeit) that originates in the understanding, and from the principle of the final purpose (Endzweck) that originates in reason, is the principle of conformity to purpose or purposiveness (Zweckmässigkeit) and originates in judgment, which is "the ability to think the particular as contained under the universal" (Kant, 1908, 179). However, the principle of the Zweckmässigkeit does not originate in the determinative kind of judgment ([which operates] under universal transcendental laws given by the understanding, [and is thus] only subsumptive" (Kant, 1908, 179), but in the judgment of the reflective type, "which is obliged to ascend from the particular in nature to the universal" (Kant, 1908, 180), because the universal is not given to him by understanding, but it has to "invent" it. In this sense, the scope of the validity of this principle is not objective and universal (they are not determinative judgments, neither synthetic $a$ priori nor a posteriori), but subjective ${ }^{15}$. Subjective validity is neither private validity, since it is not founded only in sensation, nor universal, since it is not founded in concepts. As it does not have objective validity, the principle of the reflective judgment achieves only heautonomy - legislation given by the subject to itself - and not autonomy - self legislation ${ }^{16}$. In addition, it must also be remembered that Kant points out that this principle originates only in the aesthetic reflective judgment and not in the teleological reflective judgment, because the latter has an illegitimate claim to universal validity, while the former does not pretend to add cognition about phenomena but only expresses a state of mind (Gemüt) of the subject (Kant, 1908, \$12). Thus, in Kant's critical philosophy, subjective validity, which is neither entirely universal nor entirely private, corresponds, in a strict sense, to the aesthetic field ${ }^{17}$.

The "Critique of the Aesthetic Judgment" deals with the judgment of the beautiful (which is an equivalent name for the judgement of taste) and the judgment of the

15 "That subjective [feature] of a presentation, which cannot at all become an element of cognition is the pleasure or displeasure connected with that presentation" (Kant, 1908, 189).

16 "So this transcendental principle must be one that reflective judgment gives as a law, but only to itself: it cannot take it from somewhere else (since judgment would then be determinative)" (Kant, 1908, 180).

17 Although we do not refer to "aesthetics" in the sense of the transcendental aesthetics of the Critique of Pure Rreason (Kant, 1903, 1911), but to the aesthetics of the Critique of Judgement, it must be said that the thetical function of the imagination would allow a possible unification of the two senses of aesthetics that explores Kant in the footnote to $\$ 1$ of the Critique of Pure Reason, where he establishes the distinction between transcendental aesthetics and aesthetics in the sense of Baumgarten (perspective that he himself will adopt years later with the Critique of Judgement). 
sublime ${ }^{18}$ with a similar consideration of both types of judgments according to four categories, which are cross-related. On the one hand, Kant distinguishes, negatively, the judgment of taste (or judgement of the beautiful) from the volitional judgments (of the sensible appetite, and of the useful good and the good in itself) in the first and third moment of the "Analytic of the Beautiful": according to the quality, the judgment of taste is disinterested (regarding the existence or non-existence of the object), while, according to purposiveness, it is purposiveness without purpose. On the other hand, Kant also distinguishes the judgment of taste from cognitive judgments in the second and fourth moments of the "Analytic of the Beautiful": according to the quantity, it has a subjective universality and according to the modality, it has a conditioned necessity. In general terms, subjective universality and conditioned necessity explain how it is possible for an aesthetic judgment to aspire to a higher validity than that of the merely private (in the judgment of taste it is worthless to say "everyone has his own particular taste" (Kant, 1908, $\$ 7,212)$ ), without falling into an essentialism by postulating an idea of beauty as an objective predicate ${ }^{19}$. But what is it that allows us to assume that others will judge beauty as I do, if it is a feeling and not an objective quality?

The "Critique of the Aesthetic Judgment" does not determine the effective conditions under which empirical judgments are shared; instead, it determines the formal and subjective conditions of possibility for the feeling of pleasure that is expressed in the form of the judgment of beauty (or the sublime): "it does not say that everyone will agree with my judgment, but that they ought to" (er sagt nicht, daß jedermann mit unserm Urteile übereinstimmen werde, sondern damit zusammenstimmen solle) (Kant, $1908, \$ 22$ ). It is not an obligation (an apodictic necessity, a must: ein Muss), but rather ein Sollen (a should or an ought to). In systematic terms, this subjective universality is based on the universality of the cognitive faculties that intervene in the aesthetic experience: the imagination in free play with the understanding, in the case of the beautiful, and the imagination in free play with reason, in the case of the sublime (hence the intellectualism criticized by Nietzsche). That is why Kant argues, in relation to modality, that "as a necessity that is thought in an aesthetic judgment, it can only be

18 The Critique of Judgement is divided into the "Critique of Aesthetic Judgement" and the "Critique of Teleological Judgement"; the first part is divided into "Analytic" and "Dialectic" of the Aesthetic Judgement. The "Analytic of the Aesthetic Judgement" is also divided in two: the "Analytic of the Judgement of Taste", which is the same as the judgement of the beautiful, and the "Analytic of the Judgement of the Sublime".

19 This is a kind of "aesthetic Copernican revolution", analogous to the transcendental turn in cognition. As well as the reading of Hume awoke Kant from his dogmatic dream concerning cognition, the reading of Burke awakens him from his aesthetic dogmatism (Kant, 1908, 277). 
called exemplary, i.e., a necessity of the assent of everyone to a judgment that is regarded as an example of a universal rule that we are unable to state" (Kant, 1908, \$18).

But what is Kant referring to with this conditional agreement from everyone? That it is essential for aesthetic judgments to make a claim of validity for each one, that is, that in an aesthetic judgment I take into account the other subjects of the community to which I belong, or, rather, other transcendental subjects (let us add, with Husserl, also those who are no longer and those who are not yet): "although it does not connect the predicate of beauty with the concept of the object, considered in its entire logical sphere, yet it extends that predicate over the entire sphere of judging persons" (über die ganze Sphäre der Urteilenden) (Kant, 1908, \$8). Kant calls that inclusion of others in my judgment - a consideration that saves the judgment from being limited to a particular subject and raises it to a certain range of universality - common sense:

So they must have a subjective principle, which determines [...] what is liked or disliked. Such a principle, however, could only be regarded as a common sense [...](sensus communis). [...] Only under the presupposition, therefore, that there is a common sense (by which, however, we also do not mean an outer sense, but mean the effect arising from the free play of our cognitive powers) - only under the presupposition of such a common sense, I maintain, can judgments of taste be made. (Kant, 1908, \$ 20)

Now, what place does the sphere of subjectivity (which seems to anticipate Husserlian intersubjectivity) occupy in the hierarchy of the cognitive faculties? Should we simply consider that it coincides with the domain of judgment in its reflective function? On the contrary, I believe that its intermediate place corresponds to the "ladder" of the imagination (Einbildungskraft). While it is true that reflective judgment is responsible for the transition from the phenomenal to the noumenal, to connect the sensible with the supersensible, the imagination connects the particular and the universal in many places of the critical system (especially through the synthesis of the reproduction of the first edition of the Critique of Pure Reason and through the Schematism, which is the place of a "suture" ${ }^{20}$ between sensibility and the faculty of concepts).

Unlike Heidegger, who stresses in Kant and the Problem of Metaphysics the pivotal role of Schematism (Heidegger, 1991, \$19-23), Husserl is interested in synthesis as a constituting Leistung of consciousness (Husserl, 1966, $275 \mathrm{ff}$.). He is particularly

20 "The time of Schematism sutures receptivity and spontaneity, diversity and unity; it is my power to order and the threat of ever escaping and of undoing me; it is indivisibly the possible rationality of order and the ever-renewing irrationality of lived experience; he looks towards affection, in which it is the pure flow, and towards intellectuality, since schemas appear as the possible structuring for 'series', 'content', 'order' (A 145)" (Ricoeur, 1954-55, 52). 
interested by the synthesis of the reproductive imagination that appears in the first edition of the Critique of Pure Reason, in which he finds an intentional analysis avant la lettre ${ }^{21}$, even though Kant himself did not "recognize" it ${ }^{22}$. Although Husserl compares it with his own passive syntheses, perhaps it should be rather compared with retention, as Kern suggests (Kern, 1964). In this case, it would be a positing function of consciousness; and, therefore, it would not belong, in the strict sense, to the domain of the non-positing presentification, which is phantasy (Phantasie). In a certain sense, the transcendental Einbildungskraf fulfills a positing function. Schemes, which give the rules of temporal determination (Zeitbestimmung) for the concepts, would be rules of "positing" (Setzbarkeit) in the sense that they give the conditions under which something can be inscribed in a temporal order-and it may be even possible to think of a spatial positing as well ${ }^{23}$. In fact, I believe that the well-known reduction of this function of the imagination to that of understanding in the second edition of the Critique of Pure Reason can be explained in terms of a reduction of the synthetic role of the imagination to a merely thetic role. Alexis Philonenko points out the thetic and original element of the transcendental imagination (Philonenko, 1988), and Iso Kern argues that while Kant emphasizes the relational moment, the "syn" of the syn-thetic, Husserl emphasizes the thetic moment of consciousness (Kern, 1964) ${ }^{24}$.

21 "It is of historical interest to recall here Kant's brilliant insights that are expressed in his profound but obscure doctrine of the synthesis of productive imagination, above all in his transcendental deduction from the first edition of the Critique of Pure Reason" (Husserl, 1966, 275, 410).

22 "When Kant in his great work speaks of an analytic synthesis, he means cognition deployed there in explicit forms of concepts and judgments, and this points back, for him, to a productive synthesis. But, in our view, that is nothing other than what we call passive constitution. [...] Since Kant was not in the position to recognize the essence of passive production as intentional constitution, and could not yet see the actual task of making systematically intelligible the essential necessities of the constitution of all objective formations and the path of their order of foundation, he also understandably missed the problem of evidence" (Husserl, 1966, 276, 410).

23 Although the distinction between the temporality of the internal sense and the spatiality of the external sense cannot be annulled, it could be considered an extension of this "positional function" of the schemes also to space. See for example the work of Gregg E. Franzwa, "Space and Schematism", where he considers the possibility of spatial schemes in addition to temporal ones (Franzwa, 1978).

24 "According to Husserl, because Kant defined experience as synthesis, he had already grasped the basic structure of subjectivity in general (the peculiarity of intentional connections). That Husserl's concept of synthesis, which already plays a decisive role in the Logical Investigations, can be directly or indirectly attributed to Kant, can be regarded as certain. However, it should be noted that Husserl emphasizes the moment of 'thesis' or 'setting' (the 'Doxa') of the Synthesis, whereas in Kant the accent is solely on the 'syn', on the connecting. Correlatively, a corresponding difference in the concept of being would be recorded” (Kern, 1964, 249). 
Now, can it be claimed that the characterized subjective validity, intermediate between the contingency of particular experience and the universality of the concepts, corresponds to the synthetic and transcendental function of imagination? Is there not a non-cognitive function more essential to imagination taking place in the sensus communis?

Imagination in Kant fulfills different functions, according to the domain of reason in which it is circumscribed. The imagination synthesizes (a function that later becomes that of understanding); it gives schemas, as pure transcendental imagination, or images, as empirical transcendental imagination; it gives types [Typus] in practical reason; and it gives examples in the aesthetic-teleological sphere. As it is defined in the Anthropology in Pragmatic Sense (Kant, 1907, 167), imagination belongs to sensibility and differs from sense as it allows the intuition not only in presence, but also in absence of the object (Caimi, 2011). There are three types of imagination defined in the Anthropology. Firstly, phantasy, which is "the power of the imagination, insofar as it produces images involuntarily" (Kant, 1907, 167) and resembles the dream. Then the productive or poetic imagination, which, though it is productive, is not creative because "it is not capable of producing a sense representation that was never given to our faculty of sense; one can always furnish evidence of the material of its ideas" (Kant, 1907, 167 $)^{25}$. And finally, the reproductive or evocative imagination.

The subjective validity of common sense does not seem to be connected to the transcendental imagination, that is, to the reproductive imagination that fulfills its function under the legislation of understanding in pursuit of a cognitive interest, precisely because it is the principle of the Gesetzmässigkeit that governs it and that imagination adjusts to the legality of experience in general (Jáuregui, 2011) ${ }^{26}$.

As Kant argues in the Critique of Judgment, subjective validity is subscribed to the framework of productive imagination that enters into free play with the under-

25 Kant continues by saying: "so no matter how great an artist, even a sorceress, the power of imagination may be, it is still not creative, but must get the material for its images from the senses. But these images, according to the memories formed of them, are not so universally communicable as concepts of understanding" (Kant, 1907, 168).

26 In a not yet published conference given by Heiner F. Klemme in Buenos Aires the 19th September 2016, he stated that if we ask ourselves why Kant distinguishes between understanding and imagination, two answers arise: First, imagination describes the ability to imagine something that is not given in sensibility. Secondly, there must be some form of the connection (Verknüpfung) of representations that does not express an objective unity of our representations. This must be possible because otherwise there would be no mistake and no phantasy. Every judgment would be true. If there were no difference between understanding and imagination, every judgment would be a judgment of experience (Erfahrungsurteil). 
standing or with reason: "in a judgment of taste the imagination must be considered in its freedom. This implies, first of all, that this power is here not taken as reproductive, where it is subject to the laws of association, but as productive and spontaneous (as the originator of chosen forms of possible intuitions)" (als productiv und selbstthätig (als Urheberin willkürlicher Formen möglicher Anschauungen)) (Kant, 1908, 240; Kant, 1907, 169). It is an imagination that only fits the quasi-legality of reflectiveness, of the examples that are examples of a rule that we are not able to state (einer allgemeinen Regel, die man nicht angeben kann) (Kant, 1908, \$18). Subjective or exemplary validity is, then, that of the judgments of the particular (this is beautiful, this is ugly, etc.); those that, however, see "in the particular that which is valid for more than one case" (Arendt, 2003b, 153). This is the reason why Hannah Arendt was more interested in the third Critic than in the second one ${ }^{27}$ : the Critique of Judgment deals with the particular, with the faculty of judging as a capacity for the particular, and with "sociability as a condition for exercising that capacity" (Arendt, 2003a, 35). This common sense, this consideration of others in my judgments of evaluation of the particular has a practical-political meaning, because "without other people, it would be meaningless to regulate one's own behaviour" (Arendt, 2003a, 45), and this refers to the legality that Husserl thematizes as intersubjectivity. Reflective judgments make it possible to evaluate (beurteilen) and not only to judge (urteilen), that is, they allow a reflection pertaining to the particular. But it is imagination that provides the "matter" for such reflection, which allows one to intuit that for which no concept is adequate. Thus, it may be said that the place of the true Kantian imagination is between the empirical and the transcendental.

\section{II.2. HUSSERLIAN FREE PHANTASY}

The Husserlian phantasy (Phantasie) also has cognitive functions that, in analogy with the Kantian system, can be understood as operating in a legal framework that is external to it and that also involves exemplarity. However, the role of the Phantasie in Husserl's phenomenology is considerably more relevant than that of the Einbildungskraft in the Kantian critical system. I am of course referring to the imaginative variation that allows the intuition of essences (Wesensschau), that is, the liberation

27 "The decisive difference between the Critique of Practical Reason and the Critique of Judgment is that the moral norms of the first of them are valid for all intelligible beings, while the rules of the latter limit their validity strictly to human beings. The second link is that the faculty of judging deals with individuals, who 'as such, in consideration of the universal, contain something of contingent' [Kant, Critique of Judgement, \$76]” (Arendt, 2003a, 33). 
of contingency through an operation of intuitive capture of a pure, necessary, and $a$ priori generality. This operation consists of taking as a starting point a particular given within an experience or something imagined, for example "red" or "home" (Husserl, 1976, 41), and varying that guide model with similar images to find, through an infinite multiplicity arbitrarily produced, what is common to the examples. Thus, through variation, the singular cases must be considered as examples of a rule that, in this case, will have to be reached: "It is of the universal essence of the immediately intuitive seizing upon essences that [...] it can be effected on the ground of mere presentation of exemplificative single particulars" (Husserl, 1976, 129). The result of this operation, the invariant that endures through the different modifications of the model used as a starting point, is the essence, eidos, or idea.

If, as I have anticipated above, phenomenology depends as much on the reduction of the natural to the transcendental, as on the reduction of facts to essences, then the fact that the possibility of intuiting essences depends on the phantasy explains why Husserl, in the $\$ 70$ of Ideas I, assigns to phantasy the place of the "touchstone of the phenomenological method" (Embree, 1997, 341):

Thus if one is fond of paradoxical phrases, one can actually say, and if one is means the ambiguous phrase in the right sense, one can say in strict truth, that "feigning" (Fiktion) makes up the vital element of phenomenology as of every other eidetic science, that feigning is the source (Quelle) from which the cognition of "eternal truths" is fed. (Husserl, 1976, 222)

Among the objections that have been raised against the method of the Wesensschau, one should recall Merleau-Ponty's in The Visible and the Invisible, who aims to point out that "the error of Husserl is to move from the 'without which' to 'that because of which"' (Barbaras, 2015, 66), that is, Merleau-Ponty considers that by relying on the facts, the eidetic reduction depends on the empirical without truly transcending the world. In short, Barbaras will say,

What is finally at stake here is the status of phantasy, in its double dimension: of freedom in relation to the given, which Husserl accuses, and of dependence in relation to the given, which Merleau-Ponty emphasizes. Can imagination transcend the world in which it is not necessarily inscribed? (Barbaras, 2015, 67)

This "double dimension of phantasy" is well established in the fact that it not only allows, as it has been shown, to go from the facts to the essences, to free facts from the limitation of their facticity, but also allows the reverse path, that goes from the essences to their factual possibilities. 
In a text in which Husserl explores the relationship between pure possibilities and phantasy, it is argued that the phantasy of something, insofar as it does not imply putting the phantasized in relation to the existing, is, in an ontological sense, "previous" to pure possibility. "To phantasize" an essence means posing (setzen) the phantasy of an essence, or better yet, su-pposing (versetzen) the spatio-temporal conditions of the possibility of an essence. In this sense, the phantasy would produce a sort of limitation or first "particularization" (Husserl, 1980, 562) of the essence in direction to the facts:

We must therefore distinguish what is phantasied from the pure ideal possibility $[\ldots]$ What is possible is possibly existent. [...] Hence what is phantasied is absolutely subjective and not something in itself; possibilities however, do exist in themselves. Suppositions are not phantasies but "impressions" brought about on the basis of phantasies. [...] All phantasies that are alike, that is, all like phantasy intuitions, phantasy experiences that become quasi-fulfilled in phantasy, give me the same essence; specifically, the same concrete essence. Each such essence has a range of "individual possibilities". That means that the closest individuation of an essence is a phantasy of something individual; that is, of something hovering before me hic et nunc that I can identify in the phantasy attitude only in repetition. [...] But then I can suppose that what hovers before me exists - in the nexus of my real factual existence, of course - and in that case I have a possibility. (Husserl, 1980, 569)

Now, the phantasy that intuits and the phantasy that limits essences is a motivated and guided phantasy, but not completely free, that is, drawn at its own discretion, to its own fluctuation. In its constitutive functions, phantasy is bound (verbunden or gebunden) to a presentation, to something real, to a presence in flesh and blood. It can be the individual that serves as the starting point of the variation, or the body of others in empathy (Husserl, 1973, 499), or the cultural object or the monument or the historical document that serves as a basis for the presentation of a bygone era. In all of those cases phantasy operates on and from those presentations.

But there are also in Husserl different kinds of imagination or phantasy. Literature on the subject has debated between accepting a unitary concept of imagination (Imagintation) that contains different species of consciousness (basically image consciousness (Bildbewusstsein) and phantasy (Phantasie)) and considering these two species as types of experiences irreducible to one another ${ }^{28}$. In the lectures and re-

28 With the publication of the lectures of the winter semester 1904/05 in Husserliana XXIII as text №1, the dispute comes to an end, since in them Husserl concludes that phantasy and image consciousness are irreducibility to one another. Prior to the publication of Husserliana XXIII (Husserl, 1980), the most representative view in favour of the unitary vision is that of Saraiva (1970). More recently Dubosson (2004) expresses the opposite and more accurate view. 
search manuscripts in which Husserl has dealt with these subjects, it is said that the concept of image consciousness must be reserved for what in the strict sense should be called imagination (imaginatio), that is, the types of consciousness that involve or represent by means of an image (imago) (Husserl, 1980). The term Phantasie, on the other hand, is a more general term to which, in addition to different types of phantasy, experiences that involve images can be referred; this is due to the fact that image consciousness is a complex type of consciousness in which there are two intertwined apprehensions, a perceptive one (that will be neutralized but will lend its sensible matter) and a phantasy one ${ }^{29}$. In addition to the complex image consciousness, phantasy must "include perceptual and reproductive" (Husserl, 1980, 591). Similarly to the Kantian division of imagination between free phantasy, productive imagination and reproductive imagination, in Husserl, in addition to a "mere" (bloss), "free" (freie) or "pure" (reine or pure) phantasy, and a perceptive phantasy (which takes place when watching a play $\left.{ }^{30}\right)$, there is also a completely free phantasy ${ }^{31}$.

As in Kant, the true potency of the Husserlian phantasy may not be shown in its constitutive function, when it is bound to a presentation, but only when it is free. But is a completely free phantasy the most characteristic function of this kind of consciousness? Actually not, because Husserl repeatedly questions the bare possibility of these kinds of totally free or totally unchained phantasies that would correspond to a passive phantasizing, to a surrender to the free configuration of images (Husserl, $1980,236)$. And this for, at least, two reasons. On the one hand, every phantasy is an Ichakt, that is, it is the experience of a connected and unitary self. On the other hand, as Kant warned about the productive imagination, phantasy does not create ex nihilo, but rather every phantasy could be decomposed into its impressions. Completely free phantasies would be hallucination but not phantasy. In this sense, the essence of phantasy is exhibited when it is pure or mere phantasy. It is also necessary to ask whether, as in Kant, its "legitimate" place is the aesthetic sphere. Although there are significant excerpts that point in this direction ${ }^{32}$, I believe that it is not possible, at least in Husserl,

29 For an abbreviated version of this research see Katz (2016).

30 The work is constituted as a total image-object that represents an imaginary world; the work is annulled intrinsically but not by the conflict with the surroundings, that is, not as it happens in the contemplation of an image, but annulled in itself: "the image figment is a nullity of a unique type" (Husserl, 1980, 491). Cf. Husserl (1980, 585).

31 We leave aside the types of phantasy that arise by modifying their modes of giving according to fullness, clarity or darkness, etc. And we also put aside the two possible attitudes to a phantasy: the living in it (Hineinphantasieren) and the mere floating (Vroschweben) of phantasy.

32 "Extraordinary profit can be drawn from the offerings of history, in even more abundant measure from those of art, and especially from poetry, which are, to be sure, imaginary but which, in the 
to restrict the domain of pure phantasy to its aesthetic function. The place of phantasy in Husserlian phenomenology is in fact that of the eidetic sphere. According to this, phantasy would command the border between aesthetics and logic, but its original place is between the merely natural and the pure transcendental ${ }^{33}$.

\section{BEYOND AND BELOW TRANSCENDENTAL PHILOSOPHY}

Up to this point, I have suggested that there is a common transcendental aspect in the philosophies of Kant and Husserl. Also common to both is a spirit of hierarchy, which crosses all the dimensions of the architectonic of reason and the phenomenological research. It has then been asked whether this spirit of hierarchy can also affect the transcendental foundation, subjecting it to a certain gradation. A dualist perspective (in which the transcendental is opposed to the empirical and the particular in Kantian Critical philosophy, and the factual and natural in Husserlian Phenomenology) would lead to a mere reversal of the order of foundation, that is, it would lead to a return to a naïve kind of empiricism or psychologism. But both authors find an intermediate sphere of foundation and validity that allows a triadic reading of their philosophies. This intermediate sphere between the empirical and the transcendental, between the particular and the universal, between the knowable and the supersensible depends on the possibility of intuiting something not present in the strict sense. This possibility is primarily a possibility of the Kantian Einbildungskraft or the Husserlian Phantasie.

Sometimes explicitly, sometimes implicitly, both the Kantian Einbildungskraft and the Husserlian Phantasie are present in multiple dimensions of their analysis. Assuming key functions in the theoretical reason and in the practical reason, the Kantian imagination overflows the territory of experience: Below objectifying experience, in the case of the beautiful, beyond objectifying experience in the case of the sublime, or as intuition of aesthetic ideas in the case of genius. But although Kant restricts the arbitrariness and freedom of imagination to aesthetics, we can see a wider presence of this "art hidden in the depths of the human soul" (verborgene Kunst in den Tiefen

originality of their invention of forms (Neugestaltungen), the abundance of their single features and the unbrokenness of their motivation, tower high above the products of our own phantasy and, in addition, when they are apprehended understandingly, become converted into perfectly clear phantasies with particular ease owing to the suggestive power exerted by artistic means of presentation" (Husserl, 1976, 132; $160 \mathrm{E}$ ).

33 For the passage from descriptive psychology to transcendental phenomenology through an eidetic period circa 1903, see Lavigne (2005). 
der menschlichen Seele) (Kant, 1903, 141). As Ricoeur points out, with respect to the imagination, and in particular in the Schematism, "Never has Kant been more free in regard to his epistemological concerns" (Ricoeur, 1954-1955, 52). In some places Kant has even pointed out the impossibility of thinking without images ${ }^{34}$. Moreover, the place that Kant assigns to the imagination is a preponderantly anthropological place. As argued in the Critique of Judgment, aesthetic experience, for which imagination occupies an almost legislative role, delineates what is exclusively human:

Agreeableness [satisfaction of the senses] holds for nonrational animals too; beauty [taste of the imagination] only for human beings, i.e., beings who are animal and yet rational, though it is not enough that they be rational (e.g., spirits) but they must be animal as well; the good, however, holds for every rational being as such. (Kant, 1908, § 5)

In Husserl's phenomenology, phantasy occupies a privileged position. And this is not only because it allows the intuition of essences. Husserlian phantasy allows, as I have pointed out, also the limitation of essences with the conditions of facticity, that is, it particularizes essences into possibilities as well. And furthermore, I believe there can be also pointed out an harmonizing function in experience, as it does in Hume's thought, where phantasy comes to the salvation in the face of the objection of the impossibility of recognizing a tone of blue that has never been experienced. Also in Husserl, I believe, phantasy collaborates in the concordance (Einstimmung) of experience by providing intuitions of the inactual. Phantasy brings about the "completion" or "harmonization" of what can never be given to us in flesh and blood. This is the paradigmatic case of the experience of the alter ego. Firstly, phantasy modifies the here of the one's own body (Leib) into its there, which is a condition for the possibility of the analogizing transference of the sense "own body" to the foreign "own body". Secondly, phantasy also allows the appresentations of increasingly complex degrees of subjective life that are mounted on the experience of one's own body (Husserl, 1976; Husserl, 1950, \$51-52). Moreover, to the extent that intersubjectivity is based on the possibility of the experience of the alter ego, which depends radically on functions of phantasy, the latter appears again as central with respect to the intermediate sphere of foundation: that of the "subjective and intersubjectively verifiable at all times" truths, quoted above.

34 "Rather, we must prove only that the contrast I between such an intellect and lour discursive understanding - an understanding which requires images (unseres diskursiven, der Bilder bedürftigen, Verstandes) (it is an intellectus ectypus) - and the contingency of its having this character lead us to that idea (of an intellectus archetypus), and we must prove that this idea does not involve a contradiction" (Kant, 1908, § 77). 
Now, the sphere of Husserlian intersubjectivity and the subjective sphere of Kantian common sense share the representation of the domain of what is most properly human. And if both, imagination in common sense and phantasy in intersubjectivity, play a fundamental anthropological role, can it be thought that the hierarchy of the critical and phenomenological transcendental building is thus threatened? Isn't the hierarchical order of foundation at least convulsed in the light of the importance of imagination and phantasy in the most basic and extended levels of constitution of the experience and consciousness? And would this be due - as a certain branch of contemporary phenomenology states - to the exacerbated possibility of claiming an intuitive access to the absolute, to the supersensible, to the inactual, or, on the contrary, because of the place from which the ontological question can be raised? Of course, it can be argued that the sphere of the human departs from the sphere of the transcendental subject and that, moreover, the anthropological question is an empirical question, which in no way affects transcendentalism. And yet, are not all spheres of reason subordinated to the anthropological question, including the question of freedom, as Kant has stated more than once? ${ }^{35}$ Imagination and phantasy become in the critical-phenomenological legitimation, the Quelle from which the intuition of infinite possibilities is fed - possibilities that go beyond and below the infinite horizons of reality.

\section{REFERENCES}

Arendt, H. (2003a). Conferencias sobre la filosofía política de Kant. Seminario impartido en la New School for Social Research, otoño 1970 [Lectures on Kant's Political Philosophy Delivered at the New School for Social Research in the Fall of 1970]. In Conferencias sobre la filosofía politica de Kant [Lectures on Kant's Political Philosophy] (21-143). Buenos Aires: Paidós, 2003. (in Spanish).

Arendt, H. (2003b). Imaginación [Imagination]. In Conferencias sobre la filosofía política de Kant [Lectures on Kant's Political Philosophy] (143-157). Buenos Aires: Paidós. (in Spanish).

Barbaras, R. (2015). Introduction à la philosophie de Husserl. Paris: Vrin.

Becker, O. (1973). Die Philosophie Edmund Husserl. In H. Noack (Ed.), Husserl. Darmstadt: Wissenschaftliche Buchgesellschaft.

Caimi, M. (2011). Algunas características del concepto de imaginación de en la Crítica de la razón pura [Some Features of the Concept of Imagination in the Critique of Pure Reason]. In C. Jáuregui (Ed.), Entre pensar y sentir. Estudios sobre la imaginación en la filosofía moderna [Between

35 "Philosophy, in the cosmopolitan sense of the word is directed to the following questions: What can I know? What should I do? What may I hope for? What is a human being? The first question is answered in metaphysics, the second in morals, the third in religion, and the fourth in anthropology. But deep down we could lead everything to anthropology, since the first three questions are related to the last one" (Kant, 1966, 25). 
Thinking and Feeling. Studies on the Imagination in Modern Philosophy] (217-226). Buenos Aires: Prometeo. (in Spanish).

Caimi, M. (2016). Diccionario de la Filosofía Crítica Kantiana [Dictionary on Kant's Critical Philosophy]. Buenos Aires: Colihue. (in Spanish).

Deleuze, G. (1963). La philosophie critique de Kant. Paris: PUF.

Dubosson, S. (2004). L'imagination légitimée. La conscience imaginative dans la phénoménologie proto-trascendantale de Husserl. Paris: L'Harmattan.

Eisleir, R. (1989). Kant-Lexikon. Hildesheim, Zurich, New York: Georg Olms Verlag.

Embree, L., Bahnke, E. A., Carr, D., Evans, J. C., Huertas-Jourda, J., Kockelmans, J. J., McKenna, W. R., Mickunas, A., Mohanty, J.N., Seebohm, T.M., Zaner, R.M.(Eds.). (1997). Imagination. In L. Embree (Ed.), Encyclopedia of Phenomenology. Netherlands: Kluwer Academic Publishers.

Franzwa, G.E. (1978). Space and Schematism. Kant-Studien, 69, 149-159.

Heidegger, M.(1991). Kant und das Problem der Metaphysik (GA 3). Frankfurt am Main: Vittorio Klostermann.

Husserl, E. (1950). Cartesianische Meditationen und Pariser Vorträge. Den Haag: Martinus Nijhoff.

Husserl, E. (1956). Kant und die Idee der Transzendentalphilosophie. In R. Boehm (Ed.), Erste Philosophie (1923/24). Erste Teil: Kritische Ideengeschichte. Den Haag: Martinus Nijhoff.

Husserl, E. (1966). Anallysen zur Passiven Synthesis. Aus Vorlesung und Forschungsmanuskripte (19181926) (Hua XI). Den Haag: Martinus Nijhoff.

Husserl, E. (1973). Zur Phänomenlogie der Intersubjektivität. Texte aus dem Nachlass. Zweiter Teil (1921-1928). Den Haag: Martinus Nijhoff.

Husserl, E. (1976). Ideen zu einer reinen Phänomenologie und phänomenologischen Philosophie, Erstes Buch. Allgemeine Einführung in die reine Phänomenologie (Hua III). Den Haag: Martinus Nijhoff.

Husserl, E.(1980). Phantasie, Bildbewusstsein, Erinnerung. Zur Phänomenologie der Anschaulichen Vergegenwärtigungen. Texte aus dem Nachlass (1898-1925). Den Haag, Martinus Nijhoff.

Husserl, E. (1984). Logische Untersuchungen. Den Haag, Boston, Lancaster: Martinus Nijhof.

Jáuregui, C. (2011). Juicio estético, imaginación y conciencia subjetiva en la Crítica de la facultad de juzgar de Kant [Aesthetic Judgment, Imagination and Subjective Consciousness in Kant's Critique of Judgement]. In C. Jáuregui (Ed.), Entre pensar y sentir. Estudios sobre la imaginación en la filosofía moderna [Between Thinking and Feeling. Studies on the Imagination in Modern Philosophy] (241-258). Buenos Aires: Prometeo. (in Spanish).

Kant, I. (1900). Gesammelte Schriften. Bde. I-XXIII. Berlin: Reimer.

Kant, I. (1903). Kritik der reinen Vernunft (1. Aufl. 1781). In Akademie Ausgabe (5-252). Berlin: G. Reimer.

Kant, I. (1907). Anthropologie in pragmatischer Hinsicht. In Akademie Ausgabe (1-116). Berlin: Walter Gruyter.

Kant, I. (1908). Kritik der Urteilskraft. In Akademie Ausgabe (167-485). Berlin: Walter Gruyter.

Kant, I. (1911). Kritik der reinen Vernunft. In Akademie Ausgabe (1-252). Berlin: G. Reimer.

Kant, I. (1966). Logique. Paris: Vrin.

Katz, A. (2016). Toward a Husserlian Foundation of Aesthetics. Journal of Speculative Philosophy, 30 (3), 339-351.

Kelkel, A. L. (1966). Husserl et Kant. Revue de Métaphysique et de Morale, 71 (2), 154-198.

Kern, I. (1964). Husserl und Kant. Eine Untersuchung über Husserls verhältnis zu Kant und zum Neukantismus. Den Haag: Martinus Nijhoff .

Lavigne, J.-F. (2005). Husserl et la naissance de la phénoménologie (1901-1913). Paris: PUF.

Merleau-Ponty, M. (1964). Le visible et l'invisible. Paris: Gallimard. 
Nietzsche, F. (2006). On de Genealogy of Morality. Cambridge: Cambridge University Press.

Philonenko, A. (1988). Lectura del esquematismo trascendental. Agora, 7, 9-26.

Pradelle, D. (2000). L'Archeologie du monde: Constitution de I'espace, idealisme et intuitionnisme chez Husserl. Dordrecht: Kluwer Academic Publisher.

Pradelle, D. (2012). Par-delà la révolution copernicienne. Sujet transcendantal et facultés chez Kant et Husserl. Paris: PUF.

Pradelle, D. (2016). Critique phénoménologique de l'éthique kantienne. Meta: Research in Hermeneutics, Phenomenology, and Practical Philosophy, 8 (2), 442-481.

Ricoeur, P. (1954-55). Kant et Husserl. Kant-Studien, 46 (1), 44-67.

Ricoeur, P. (1986). Sur la phénoménologie. In A lécole de la phénomenologie. Paris: Vrin.

Saraiva, M. M. (1970). L'imagination selon Husserl. Den Haag: Martinus Nijhoff.

Welton, D. (Ed). (1999). The Essential Husserl. Basic Writings in Transcendental Phenomenology. USA: Indiana University Press. 